Mirela Gusić

Suzana Matić

Iva Mrak

Anja Slovenc

Sveuciliste u Zagrebu, Edukacijsko-rehabilitacijski

fakultet, studentice

Luka Bonetti

Svenčilište u Zagrebu, Edukacijsko-rehabilitacijski

fakultet, Odsjek za oštécenja sluba

\section{Stavovi i informiranost mladih osoba o stečenom oštećenju sluha}

\author{
Attitudes and awareness of young people \\ about acquired hearing loss
}

\begin{abstract}
SAŽETAK
Stečeno oštećenje sluha jedno je od najčešćih kroničnih stanja odrasle i starije dobi. Njegov snažan socioekonomski utjecaj razvijene zemlje nastoje umanjiti preventivnim aktivnostima, a jedna od najbitnijih je bolje informiranje javnosti o svim implikacijama, te senzoričke promjene na kvalitetu života. Pritom je najbitnije sustavno informiranje mladih osoba koje su, zbog nedostatka formalnih mehanizama zaštite, pod dodatnim rizikom stjecanja oštećenja sluha zbog čestog izlaganja rekreacijskoj buci. Promjena znanja ove subpopulacije o stečenom oštećenju sluha i njegovim posljedicama ima potencijal promjene njihovih stavova o prevenciji, te u konačnici i mijenjanje rizičnih ponašanja koja pridonose razvoju oštećenja sluha u odrasloj ili starijoj dobi. Zato je važno poznavati početna znanja i stavove mladih osoba o stečenom oštećenju sluha, radi uvida u potrebu aktivnog i sustavnog stručnog rada na njihovoj promjeni, s ciljem podrške prevenciji teškoća slušanja uzrokovanih bukom u ovoj rizičnoj subpopulaciji. U ovom su istraživanju, pomoću ad hoc online upitnika, ispitani stavovi 112 mladih osoba iz čitave Hrvatske o stečenom oštećenju sluha. U skladu s početnom pretpostavkom istraživanja, pokazalo se da su stavovi sudionika o oštećenju sluha uglavnom negativni ili nedovoljno diferencirani, što govori o potrebi sustavnijeg obrazovanja mladih osoba o fenomenu oštećenja sluha, s ciljem prevencije oštećenja sluha stečenog u odrasloj i starijoj dobi.
\end{abstract}

\begin{abstract}
Hearing loss is one of the most common chronic conditions in adult and elderly population. One of the most important preventive activities, which developed countries are trying to implement in the attempt to reduce the socio-economic impact of acquired hearing loss, is to inform the public better about the broad implications of this sensory change on the quality of life. It is of particular interest to inform systematically adolescents and young adults who, due to the lack of formal protection mechanisms, are at the increased risk of acquiring hearing loss later in life because of their frequent exposure to recreational noise. Altering the knowledge of this particular subpopulation about acquired hearing loss and its consequences can potentially change their attitudes towards prevention and ultimately behaviours that contribute to the development of hearing loss in the future. For this reason, it is important to be acquainted with the initial knowledge and attitudes of adolescents and young adults on acquired hearing loss in order to gain insight into the need for active and systematic professional efforts towards changing them, with the ultimate aim of supporting the prevention of noise-induced hearing loss in this subpopulation. In this study, an ad hoc online questionnaire was used to examine the attitudes of 112 young people from Croatia about acquired hearing loss. According to the initial assumption of the research, mostly negative or insufficiently differentiated attitudes about acquired hearing loss were observed, suggesting the need for a more systematic education of adolescents and young adults about hearing loss, in order to ensure the efficient support for the prevention of noise induced hearing loss later in life.
\end{abstract}

Ključne riječi: mlade osobe oštećenje sluha - buka stavovi prevencija

Keywords: young people hearing loss noise attitudes prevention 


\section{UVOD}

S procijenjenom pojavnošću od 2 do $25 \%$ po dekadama od dobi od 45 do 65 godina života, odnosno od $30 \%$ u dobi iznad 65. godine života, stečeno oštećenje sluha najčešća je senzorička promjena i kronično stanje odrasle i starije dobi National Institute on Deafness and Other Communication Disorders - NIDCD, 2016; World Health Organization WHO, 2013). S obzirom na pojavnost i brojne posljedice, njegov se ekonomski utjecaj mjeri u milijardama (Bonetti, Ratkovski i Šimunjak, 2017), zbog toga mnoge razvijene zemlje ulažu u preventivne aktivnosti s ciljem minimiziranja komunikacijskih, socioemocionalnih, ekonomskih i drugih učinaka stečenog oštećenja sluha. Jedna od najvažnijih preventivnih aktivnosti svakako je bolje informiranje javnosti o implikacijama stečenog oštećenja sluha i njegovom utjecaju na kvalitetu života, kojim se, među ostalim, nastoji umanjiti i broj osoba sa stečenim oštećenjem sluha u odrasloj/starijoj dobi. Naime, procjenjuje se da je 16 $\%$ stečenih oštećenja sluha posljedica izlaganju buci i da je rekreacijska buka, kojoj se pogotovo izlažu mlade i mlađe odrasle osobe, osim buke na radnome mjestu, jedan od glavnih razloga velikog povećanja broja osoba sa stečenim oštećenjem sluha posljednjih desetljeća (Meinke i Dice, 2007; Nelson, Nelson, Concha-Barrientos i Fingerhut, 2005). Budući da se oštećenje sluha stečeno zbog izlaganja buci može u potpunosti spriječiti, preventivne aktivnosti naglašeno su usmjerene informiranju upravo mladih osoba o rizicima izlaganja buci na zdravlje sluha u odrasloj/starijoj dobi.

Velika većina mladih osoba redovito se izlaže bučnim aktivnostima (Australian Hearing, 2010; Olsen Widén i Erlandson, 2004) i u velikom postotku već osjeća rane simptome slušnih mikrotrauma (Gilles i sur., 2012; Berg i Serpanos, 2011; Chung, Des Roches, Meunier i Eavey, 2005), koje kumulativnim učinkom uzrokuju trajne posljedice na zdravlje sluha u kasnijoj dobi (Meinke i Dice, 2007; Chung i sur., 2005). Istodobno je informiranost mladih osoba o stečenom oštećenju sluha - čiji je uzrok izlaganje buci - niska (Danhauer i sur., 2012; Widen, Bohlin i Johansson, 2011; Chung i sur., 2005), a stavovi o zaštiti zdravlja sluha negativni (Gilles i sur., 2012; Chung i sur., 2005), te minorizirajući u smislu utjecaja gubitka sluha na kasniju kvalitetu života (Chung i sur., 2005). Čini se da olako shvaćanje rizika stjecanja oštećenja sluha proizlazi zbog neinformiranosti ili informiranosti, koja je nedovoljna za stvaranje predodžbe o posljedicama trenutnog izlaganja buci, kumulativnoj prirodi tih posljedica i utjecaju razvijajućih teškoća slušanja na kvalitetu kasnijeg života (Rosandić i Bonetti, 2014). Zato je bolje organizirano informiranje mladih i javnosti općenito o implikacijama stečenog oštećenja sluha jedan od prevencijskih prioriteta zdravstvenih sustava razvijenih zemalja.

Informiranje javnosti o stečenom oštećenju sluha $u$ konačnici je usmjereno mijenjanju rizičnih ponašanja, što uključuje i mijenjanje znanja i na njima zasnovanih stavova o buci i njezinom utjecaju na zdravlje sluha, kao i oštećenju sluha općenito (Griest, Folmer i Martin, 2008). Stav je relativno trajna organizacija vjerovanja, osjećaja i bihevioralnih tendencija prema socijalno značajnim objektima, događajima, grupama ili simbolima (Hogg i Vaughan, 2010). Zasnovani su na kognitivnim, afektivnim i bihevioralnim temeljima, od kojih jedan može biti presudniji za formiranje stava, što se u praktičnom smislu može iskoristiti za njihovo mijenjanje, pogotovo kognitivno slabije diferenciranih stavova (Katz, 1960). Slabije kognitivno diferencirani stavovi povezani su s ponašanjem nositelja stava kroz opažanje njegove vlastite interakcije s objektom stava (Aronson, Wilson, Akert, 2005). Iz perspektive oštećenja sluha stečenog zbog izlaganja buci, ovu je spoznaju moguće povezati $s$ nedostatnim znanjima javnosti $O$ kumulativnim učincima buke na zdravlje sluha i teškim implikacijama stečenog oštećenja sluha za kvalitetu života, iz kojih proizlaze stavovi temeljeni na iskustvu izlaganja buci, koje je - pogotovo kod mladih osoba - velikom većinom pozitivno zbog uglavnom oporavljajućeg učinka odmora na slušni organ. Navedeno ilustrira podatak da mlade osobe u velikom broju imaju najmanje ravnodušan stav prema oštećenju sluha, usprkos iskustvu negativnih slušnih reakcija na izlaganje buci poput osjećaja dugotrajnog šuma u ušima (Rosandić i Bonetti, 2014).

Neznanje na kojem se dijelom temelji za sluh rizično izlaganje, zapravo uključuje općenito nepoznavanje javnosti o sveobuhvatnošću posljedica stečenog oštećenja sluha, odnosno njegove česte progresije iz perceptivnog $u$ komunikacijski, potom socijalni, emocionalni, financijski, fizički i kognitivni problem (Bonetti i sur., 2017). Jedna od najtežih posljedica stečenog oštećenja sluha je socijalna izolacija (Strawbridge, Wallhagen, Shema i Kaplan, 2000), koja se javlja kao obrambeni mehanizam zbog nakupljanja stresnih negativnih komunikacijskih i socijalnih iskustava koja imaju višestruke negativne fizičke i psihičke posljedice poput depresije, razdražljivosti, tjeskobe, anksioznosti, straha, socijalnih fobija, osjećaja nesposobnosti, umora, glavobolja, problema sa spavanjem i drugih (Trychin, 2002; Carmen, 2004). Gubitkom samopouzdanja i samopoštovanja zbog komunikacijskih neuspjeha povećavaju se izgledi za socijalnu izolaciju (Monzani, Galeazzi, Genovese, Marrara i Martini, 2008), a potiče je i rastući osjećaj negativnog socijalnog isticanja zbog neodgovarajućih reakcija na poruke drugih, zbog kojih osobe sa stečenim oštećenjem sluha postaju i socijalno marginalizirane (Hogan, 2001). Izolacija, samoizolacija i socijalna marginalizacija osoba sa stečenim oštećenjem sluha mogu voditi do depresije i smanjenja kognitivnog funkcioniranja (Naramura i sur., 1999; Gurgel i sur., 2014), čime posljedice stečenog oštećenja sluha kulminiraju u smislu utjecaja na kvalitetu života.

Ovako organizirane informacije o implikacijama stečenog oštećenja sluha mladim su osobama nedostupne (Rosandić i Bonetti, 2014), pa im površna znanja omogućavaju tek formiranje stereotipnih i većinom negativnih stavova o slušnim teškoćama kao problemu starije populacije i starosti. S time se mlade i mlade odrasle osobe teško povezuju zbog svojeg zdravlja i vitalnosti (Keppler, Dhooge i Vinck, 2015; Australian Hearing's Health Report, 2008; Crandell, Mills i Gauthier 2004). Međutim, s obzirom na kumulativni učinak buke na zdravlje sluha, čak 1.1 milijardi trenutno za sluh nezabrinutih mladih ljudi (između 12 i 35 godina) nosi rizik stjecanja oštećenja sluha uzrokovanog bukom (WHO, 2017). S obzirom na iznesene teške osobne i društvene posljedice stečenog oštećenja sluha, nužno ja znati kakve informacije mlade osobe imaju o stečenom oštećenju sluha te kakve imaju stavove prema tom problemu. Važnost tih spoznaja je mogućnost planiranja promjena potencijalno negativnih $\mathrm{i} / \mathrm{ili}$ 
nedovoljno diferenciranih stavova o stečenom oštećenju sluha, koje mogu utjecati na smanjenje rizičnih ponašanja u budućnosti (Griest i sur., 2008), i to u najizloženijoj i najosjetlivijoj (Aronson i sur., 2005) populaciji - mladih osoba. Cilj ovog rada je ispitati informiranost i stavove mladih osoba iz čitave Hrvatske o stečenom oštećenju sluha, radi uvida u njihova početna znanja i razmjere potrebe sustavnijeg obrazovanja mladih u Hrvatskoj o fenomenu oštećenja sluha. $U$ skladu $\mathrm{s}$ ranijim spoznajama $\mathrm{O}$ informiranosti i stavovima mladih o buci i/ili stečenom oštećenju sluha (Keppler i sur., 2015; Rosandić i Bonetti, 2014; Danhauer i sur., 2012; Gilles i sur., 2012; Widen i sur., 2011; Australian Hearing's Health Report, 2008; Chung i sur., 2005; Crandell i sur., 2004), u radu je pretpostavljeno da je informiranost mladih osoba u Hrvatskoj o stečenom oštećenju sluha niska, a stavovi uglavnom negativni.

\section{METODE}

U istraživanju je sudjelovalo 112 mladih osoba (38 muškog i 74 ženskog spola) iz Republike Hrvatske u dobi od 18 do 33 godine $(\mathrm{M}=21.91, \mathrm{SD}=2.63)$. Najveći dio sudionika istraživanja $(62 \%)$ bili su studenti, i to biomedicinskih (farmacija, biotehnologija, medicina), humanističkih (pedagogija, hrvatski i strani jezici), biotehničkih (agronomija), tehničkih (informatika, elektrotehnika, građevinarstvo, inženjerstvo okoliša, konstrukcijsko strojarstvo), prirodnih (matematika, geologija) i društvenih područja (učiteljski studij), sa sveučilišta i veleučilišta iz čitave zemlje, dok je manji dio sudionika bio srednje (27\%) ili visoke stručne spreme (11 \%). Prikupljanje podataka obavljeno je tzv. tehnikom „snježne grude“, koja pretpostavlja inicijalno identificiranje i kvalificiranje skupa pojedinaca unutar populacije - u ovom slučaju mladih osoba, kod kojih postoji opravdana sumnja da mogu steći oštećenje sluha jer se u velikom udjelu često ili redovito izlažu rekreacijskoj buci (WHO, 2017), koji ujedno pomažu privući ostale sudionike istraživanja (Sindik, 2014).

Prikupljanje podataka provedeno je putem ad hoc upitnika, postavljenog na servisu Google Forms u studenom 2017. godine. Unaprijed je predviđeno da upitnik sadrži samo 10 vrlo jednostavnih pitanja, sadržajno i stilski primjerenih pretpostavljenom (ne)znanju sudionika o stečenom oštećenju sluha (Keppler i sur., 2015; Rosandić i Bonetti, 2014; Danhauer i sur., 2012; Gilles i sur., 2012; Widen i sur., 2011; Australian Hearing's Health Report, 2008; Chung i sur., 2005; Crandell i sur., 2004). Dva pitanja odnosila su se na demografske podatke (o dobi i spolu). Četiri pitanja otvorenog tipa ispitivala su asocijacije sudionika istraživanja na pojam „oštećenje sluha“, „slušno pomagalo“, „osobe s oštećenjem sluha“, „osobine osoba koje imaju oštećenje sluha“, te razloge zbog kojih bi se sudionici istraživanja zabrinuli za svoje slušanje. Četiri preostala pitanja bila su DA/NE pitanja, kojima se ispitivala informiranost sudionika istraživanja o rehabilitacijskim opcijama i očekivanja od njima poznatih rehabilitacijskih opcija.

Prije ispunjavanja upitnika, sudionici istraživanja su elektroničkom porukom upoznati o cilju prikupljanja podataka te im je zajamčena anonimnost. Njihovi su odgovori prikupljani u razdoblju od 3 dana, nakon toga se pristupilo opisnoj analizi i sumiranju podataka. Pritom su se odgovori na pitanja otvorenog tipa, dogovorom autora, grupirali prema smislu, radi lakšeg interpretiranja zbog različitih stilova izražavanja sudionika.

\section{REZULTATI I RASPRAVA}

Koja ti riječ prva padne na pamet kad čuješ riječ ,oštećenje sluba"? - najveći je broj sudionika na to pitanje istraživanja odgovorio sa: ,gluh/gluhoća“ (26\%), ,slušni aparat“ (8\%), „uho" (8\%), „nagluhost" (7 \%) te „bolest“ (5\%). Iznenađujuće, među odgovorima zastupljenim u manje od 5 $\%$ slučajeva bili su odgovori „glazba“ i „slušalice“, a očekivano i negativni odgovori poput ,invalidnost", „loše“, „hendikep“, „,nezgoda“, „užas“, „bol“ „tuga“ ili „tišina“, te u jednom slučaju „znakovni jezik“. Ukupno gledajući, odgovori poput navedenih, koji se mogu smatrati reprezentacijom negativnog stava prema oštećenju sluha, pojavili su se u više od $20 \%$ slučajeva.

Koja ti riječ prva padne na pamet kad ínješ riječi „slušno pomagalo"? - na to pitanje u $35 \%$ slučajeva prva je asocijacija sudionika istraživanja bila samo „aparat“ (35\%), zatim „uho“ (8 \%), pa „starost/stariji“ (8\%) i „gluh/gluhoća“ (7 $\%$, a medu odgovorima zastupljenim u manje od $5 \%$ slučajeva bili su odgovori „oštećenje sluha“, „poteškoća“, te negativni odgovori poput ,jadno“, „skupoća“, „dodatna briga“, „buba u uhu“, „plastika iza uha“, „onemogućenje“ ili „ružan izgled“, ali i pozitivni poput „ništa strašno“, „spas“, „mogućnost" ili „pomoć“. Uključujući negativne asocijacije na ovo tehničko rješenje za pomoć u slušanju te asocijacije na starost i gluhoću, ukupno $32 \%$ odgovora sudionika istraživanja na ovo pitanje moglo se smatrati reprezentacijom negativnog stava prema prvoj i najvažnijoj rehabilitacijskoj opciji nakon stjecanja oštećenja sluha.

Koje osobe ili osobine povezuješ s oštećenjem sluba? - na to pitanje najčešći je odgovor očekivano bio "starije osobe" (33 $\%$, zatim ,gluhe/nagluhe/gluhonijeme osobe“ (18\%). U 6 $\%$ slučajeva odgovor je bio „ne znam“, a u $4 \%$ slučajeva „osobe koje glasno govore“. Vrlo je nepovoljno što su se među odgovorima našle asocijacije - poput „dezorijentiranost“, „nestrpljivost“", „tvrdoglavost“, „povučenost", „hendikepiranost" (ukupno u $5 \%$ slučajeva). Pozitivno je što su neki sudionici, kao osobine osoba s oštećenjem sluha, naveli - „strpljivost“, „samopouzdanje“, „snalažljivost", „upornost", „simpatičnost" i „blagost" (ukupno u $6 \%$ slučajeva). Zanimljivo je primijetiti da je $8 \%$ sudionika istraživanja $\mathrm{s}$ oštećenjem sluha povezalo glazbenike, radnike izložene buci te mlade, što je svakako povoljan nalaz. Međutim, asocijacije na starost, na samo oštećenje i nepoželjne ljudske osobine, koje su se pojavile u ukupno $55 \%$ slučajeva, svakako se mogu smatrati reprezentacijom pretežno negativnog stava sudionika istraživanja prema osobama s oštećenjem sluha.

Zbog čga bi se zabrinuo za svoje slušanje? - na to pitanje 59 $\%$ sudionika istraživanja odgovorilo je u slučaju pojave teškoća slušanja (29\% kod slušanja zvukova općenito te $13 \%$ kod slušanja glazbe) ili komunikacijskih teškoća (17\%). Vrlo je nepovoljan nalaz da je čak $13 \%$ sudionika na ovo pitanje odabralo odgovor „ne znam“ ili „ni zbog čega“. S druge strane, pozitivni su nalazi da bi se $8 \%$ sudionika zabrinulo za svoje slušanje „zbog kvalitete života“, $6 \%$,zbog slušalica 
koje koriste“, a $3 \%$ „zbog bučnih strojeva s kojima rade“. Među ostalim odgovorima, zastupljenim u ukupno $4 \%$ slučajeva, javili su se i ovi: „zbog osjećaja zakinutosti“, „zbog nedostatka“, „zbog osjećaja tereta okolini“ i „zbog starosti“. Ukupno gledajući, odgovori sudionika na to pitanje izrazito su nepovoljni jer ih ukupno više od $75 \%$ smatra da se za sluh ne treba brinuti, ili da se treba zabrinuti tek u budućnosti - kada nastupe prvi simptomi gubitka sluha ili u starosti.

$\mathrm{Na}$ tvrdnju da se oštećenje sluha može izliječiti - $49 \%$ sudionika odgovorilo je potvrdno. Nadalje, na tvrdnju da slušna pomagala omogúcuju normalno slušanje, čak $86 \%$ sudionika odgovorilo je potvrdno. Vjerojatno je zato $94 \%$ sudionika istraživanja odgovorilo da bi nosilo slušno pomagalo, da im je dijagnosticirano oštećenje sluha. Konačno, u skladu s vrlo pozitivnim pogledom na rehabilitacijske opcije, čak $37 \%$ sudionika istraživanja smatra da oštećenje sluha nema utjecaj na kvalitetu života, uključujući društveni život i partnerske veze.

Izneseni rezultati opisne analize odgovora 112 mladih osoba na 8 pitanja, kojima se ispitivala njihova informiranost i njihovi stavovi o stečenom oštećenju sluha, potvrđuju početnu pretpostavku o slaboj informiranosti i pretežno negativnim stavovima ove subpopulacije $u$ Hrvatskoj o stečenom oštećenju sluha. Manji dio sudionika istraživanja $(20 \%)$ oštećenje sluha povezivao je s izrazito negativnim pojmovima (poput „užas“, „bolest“, „loše“, „hendikep“, „tuga“ i „bol“), a velika preostala većina asocijacija bila je neutralna (povezivanje s pojmovima poput „uho“ ili „gluh/gluhoća/nagluhost)“, dok pozitivne asocijacije očekivano nisu bile zabilježene. Asocijacije na slušno pomagalo kod svakog trećeg sudionika su neutralne (neodređene) ili negativne (uključujući nepovjerenje $u$ tu tehnologiju te njezine ekonomske i estetske aspekte), ali u vrlo malom dijelu i izrazito pozitivne (u smislu rehabilitacijske opcije). Budući da je dodjela slušnog pomagala, odnosno reaktivacija preostalog sluha, najvažnija rehabilitacijska opcija jer ova tehnologija poboljšava kvalitetu života (Kochkin, 2012; Pronk i sur., 2011), te s obzirom na dob sudionika, njihovu tehničku pismenost $i$ pretpostavljenu otvorenost prema primjeni tehnologije općenito, kao i na masovnu primjenu osobne audiotehnologije u javnosti, pronađen skroman broj pozitivnih stavova prema elektroakustičkoj tehnologiji ne ohrabruje.

Među obeshrabrujuće nalaze može se ubrojiti povezivanje oštećenja sluha sa starošću kod trećine sudionika $i$, doduše $u$ manjem dijelu, $s$ negativnim osobinama (poput „dezorijentiranosti“, „nestrpljivosti“ ili „tvrdoglavosti“"). Stečeno oštećenje sluha jedno je od najčešćih kroničnih stanja treće životne dobi (WHO, 2013) i očekivano je da ga društvo povezuje s tom subpopulacijom. Međutim, činjenica da su sudionici istraživanja oštećenje sluha povezivali sa starošću može se smatrati negativnim nalazom jer je otprije poznato da mlade osobe, pogotovo u zapadnim društvima, starost i starije osobe općenito doživljavaju uglavnom negativno, kao dijametralnu suprotnost vitalnosti, povezanu s nepoželjnim osobinama (poput zahtjevnosti, zaboravljivosti, rigidnosti, dosade ili konzervatizma), sa smanjenom funkcionalnošću i kapacitetima (pogotovo kognitivnim), s fizičkim i drugim ograničenjima, usamljenošću, boležljivošću i konceptom propadanja, socijalnom inkompetencijom, te socijalnim opterećenjem ili troškom zbog dojma o niskom socijalnom doprinosu starijih ljudi (Stock, 2014; Australian Human Rights Commission, 2013; Arnold-Cathalifaud, Thumala, Urquiza i Ojeda, 2008; Power, 1992). Stoga se uočeno povezivanje stečenog oštećenja sluha sa starošću, koja uglavnom predstavlja negativni koncept za mlade osobe, u širem se smislu može smatrati poistovjećivanjem komunikacijskih posljedica gubitka sluha $s$ negativnim konotacijama starenja. Ovaj je podatak nepovoljan i zato što pridonosi stereotipu i predrasudama o starijim osobama, a time i njihovoj stigmatizaciji, koja je jedna od glavnih prepreka uspješnoj rehabilitaciji odraslih i starijih osoba sa stečenim oštećenjem sluha zbog demotivirajućeg učinka na traženje stručne pomoći (Southall, Gagné i Jennings, 2010; Wallhagen, 2010).

Pregledom odgovora sudionika istraživanja na pitanja otvorenog tipa, ponovno (raniji zaključak vidi u Rosandić i Bonetti, 2014) ostaje dojam da mlade i mlađe odrasle osobe u Hrvatskoj ne prepoznaju jasan uzročno-posljedični slijed između izlaganja buci i kasnije kvalitete života povezane $s$ promjenom funkcije sluha. Čini se da su površne informacije i prateći nedovoljno diferencirani stavovi o oštećenju sluha, kao i kumulativna priroda djelovanja buke na zdravlje sluha koja kamuflira njezine moguće posljedice, sudionike istraživanja usmjerili na razmišljanje da se oštećenje sluha stječe spontano, samo starenjem, a ne i trenutnim ponašanjem. Razumljivo, mlade i mlađe osobe vjerojatno se osjećaju odvojeno od problema koje nosi starenje, a glasni su događaji sastavni dio mladenačkog života i imaju vrlo jaku socijalnu komponentu. Ipak, nalaz da svaki treći sudionik istraživanja stjecanje oštećenja sluha smatra nebitnim za kvalitetu života upućuje da mlade osobe u Hrvatskoj, kao i o mnogim drugim pitanjima vezanim za njihovo zdravlje, trebaju biti bolje informirane o funkcionalnim i drugim implikacijama ovog oštećenja. $\mathrm{Na}$ isto upućuje $\mathrm{i}$ (vrlo) optimističan pogled većine sudionika istraživanja na rehabilitaciju i doseg pomoći tehnologije slušnih pomagala. Spoj utvrđenih pretežno neutralnih i negativnih stavova o osobama s oštećenjem sluha, te nerealnog pogleda na tehnologiju slušnih pomagala, može se povezati s kasnijom niskom prevalencijom nošenja slušnih pomagala zbog stigme i razočaranja u korist koju pružaju (Verma i sur., 2017).

Budući da se oštećenja sluha stečena u odrasloj ili starijoj dobi dijelom mogu prevenirati ili klinički ublažiti izbjegavanjem ponašanja rizičnih za zdravlje sluha u mladosti (poput izlaganja buci), uputno je stručne napore usmjeriti mijenjanju izloženih nalaza, i to boljim, organiziranim informiranjem mladih osoba, odnosno plasiranjem znanja koje će učvrstiti pozitivne stavove prema prevenciji oštećenja sluha i time smanjiti rizična ponašanja poput čestog i pretjeranog izlaganja buci (Griest i sur., 2008). Povećanje znanja o utjecaju buke na sluh i posljedicama stečenog oštećenja sluha na kvalitetu života može biti pogotovo pozitivno iz perspektive ranog otkrivanja stečenog gubitka sluha, koje je ključno su za maksimalno ublažavanje njegovih dugoročnih učinaka (McMahon i sur., 2013) i maksimalnu iskoristivost tehnologije slušnih pomagala (Davis, Smith, Ferguson, Stephens i Gianopoulos, 2007). Uzimajući u obzir da tri od četiri sudionika istraživanja smatraju da se za sluh ne treba brinuti, ili da se treba zabrinuti tek kada nastupe slušne i komunikacijske teškoće, očito treba raditi na boljem 
informiranju, odnosno većem znanju mladih osoba, kojim bi trebalo postići da se iste teškoće preveniraju ili pojave u klinički blažoj varijanti.

Skromni broj pozitivnih odgovora sudionika istraživanja - poput onih koji se odnose razumijevanje truda koji osobe s oštećenjem sluha moraju ulagati u komunikaciju, onih koji povezuju oštećenje sluha s izlaganjem buci ili onih koji ga povezuju s kasnijom kvalitetom života - pokazuje da među mladima postoji određena svijest o važnosti zdravlja sluha, ali i o rizicima te simptomima stečenog gubitka sluha. Zbog nedostatka formalnih mehanizama zaštite (kakvi postoje, naprimjer, u profesionalnom okruženju), nadogradnja njihovih uočenih površnih znanja sustavnom diseminacijom ciljanih sadržaja o prevenciji oštećenja sluha izazvanog bukom u obrazovnim ustanovama može dati dobre rezultate (Griest i sur., 2007; Folmer, 2005; Folmer, Griest i Martin, 2002), dok drugi način diseminacije znanja može biti internet, kao preferirani medij u ovoj subpopulaciji (Rosandić i Bonetti, 2014). Konačno, u povećanje informiranosti i promjenu stavova mladih osoba o prevenciji stečenog oštećenja sluha očito treba uključiti i medicinske djelatnike, s obzirom na to da se utvrđena velika spremnost za nošenje slušnih pomagala može tumačiti kao povjerenje prema savjetima medicinske struke (Rosandić i Bonetti, 2014). Kao primjere navedenog, moguće je navesti više programa ili kampanja za prevenciju bukom izazvanog oštećenja sluha, u sklopu kojih se mlade osobe osnovnoškolskog ili srednjoškolskog uzrasta educiraju o opasnostima izlaganja buci putem informacija o anatomiji i fiziologiji slušanja, činjenicama vezanim za oštećenje sluha izazvano bukom, opasnim razinama buke, ranim znakovima pojave slušnih teškoća, posljedicama oštećenja sluha i načinima njegove prevencije, stručnjacima kojima se može obratiti u slučaju primjećivanja teškoća i važnosti redovitih testiranja sluha; informacije se diseminiraju putem višednevnih, jednodnevnih ili čak jednosatnih predavanja $i$ radionica, izložbi, virtualnih izložbi, mrežnih stranica, videomaterijala, demonstracija, treninga, upitnika i kvizova, online igara i aktivnosti te brošura, savjeta za roditelje, postera i sličnih materijala (Clark, 2013). Većina tih programa je evaluirana, pokazalo se da imaju značajne kratkotrajne i dugotrajne učinke u smislu promjene stavova prema prevenciji stečenog oštećenja sluha, u čemu važnu ulogu ima istraživački pristup učenju novih znanja zagovaran u preventivnim programima, koji podrazumijeva da mladi slušaju i promatraju, zatim mjere, istražuju, analiziraju i propitkuju, predviđaju i testiraju odgovore, te logički zaključuju o prezentiranim informacijama (Clark, 2013).

\section{ZAKLJUČAK}

Sudeći prema rezultatima ovog istraživanja, mlade i mlađe odrasle osobe u Hrvatskoj nemaju dovoljno informacija niti pozitivne stavove prema stečenom oštećenju sluha: pogrešno ga identificiraju kao problem starosti, iako svojim trenutnim ponašanjem mogu izravno utjecati na njegovu pojavu, imaju nerealne poglede na rehabilitacijske opcije i komunikacijske ishode dodjele slušnih pomagala, te ne shvaćaju težinu mogućih posljedica stjecanja oštećenja sluha na produktivnost i kvalitetu života. Ovakvi rezultati govore o potrebi kreiranja preventivnih programa i programa podizanja svijesti o implikacijama stečenog oštećenja sluha, gubitku sluha kao nepovratnom događaju, te slušnim pomagalima kao tehnologiji s ograničenim opsegom pomoći komunikaciji (Ross, 2000). S obzirom na sveobuhvatne i vrlo skupe ukupne posljedice stečenog oštećenja sluha, u interesu je društva ulagati u organizirano predstavljanje znanja koja mogu spriječiti ili umanjiti šansu da njegovim članovima stečeno oštećenje sluha u budućnosti predstavlja prepreku u osobnom, profesionalnom ili socijalnom angažmanu. Budući da su mlade osobe rizična skupina u kojoj nema formalnih mehanizama zaštite, kao dobar način diseminacije znanja mogu se iskoristiti sustavi formalnog obrazovanja, moderni komunikacijski mediji (poput interneta), te osobe unutar obrazovnog i zdravstvenog sustava čija će stručnost, vjerodostojnost, privlačnost i autoritativnost u ulozi izvora novog znanja, zbog podložnosti autoritetu, osjećaja sigurnosti i smanjenja potrebe preispitivanja novog znanja te socijalno privlačnih i ugodnih osjećaja koji proizlaze iz poistovjećivanja s atraktivnim i autoritativnim izvorom novog znanja (Perloff, 2016), povećati šanse za promjenu stavova mladih osoba o stečenom oštećenju sluha te, u skladu s tim, njihovih ponašanja prema zdravlju sluha.

\section{LITERATURA}

1) Arnold-Cathalifaud, M., Thumala, D., Urquiza, A. i Ojeda, A. (2008). Young people's images of old age in Chile: Exploratory research. Educational Gerontology, 34(2), 105-123.

2) Aronson, E., Wilson, T. D. i Akert, R. M. (2005). Socijalna psibologija. Zagreb: Mate.

3) Australian Hearing (2010). Binge listening: Is exposure to leisure noise causing hearing loss in young Australians? Posjećeno 12.12.2017. na mrežnoj stranici http://www.hearing.com.au/wpcontent/uploads/2013/09/ binge-listening.pdf

4) Australian Hearing's Health Report (2008). Is Australia Listening?. Attitudes to hearing loss. Posjećeno 12.12.2017. na mrežnoj stranici https://www.hearing.com.au/wpcontent/uploads/2013/09/Is-Australia-Listening.pdf

5) Australian Human Rights Commission (2013). Fact or fiction? Stereotypes of older Australians. Research report. Sydney, Australia: Australian Human Rights Commission. Posjećeno 10.12.2017. na mrežnoj stranici http://www.humanrights.gov.au/publications-home/all 6) Berg, A. L. i Serpanos, Y. C. (2011). High Frequency Hearing Sensitivity in Adolescent Females of a Lower Socioeconomic Status Over a Period of 24 Years (19852008). Journal of Adolescent Health, 48(2), 203-208.

7) Bonetti, L. Ratkovski, I. i Šimunjak, B. (2017). Suvremena rehabilitacija odraslih osoba sa stečenim oštećenjem sluha. Liječnički vjesnik. U tisku.

8) Carmen, R. (ur) (2004). The Consumer Hanbook on Hearing Loss and Hearing Aids: A Bridge to Healing. 4. izd. Sedona, Arizona: Auricle Ink Publishers.

9) Chung, J. H., Des Roches, C. M., Meunier, J. i Eavey, R. D. (2005). Evaluation of Noise-Induced Hearing Loss in Young People Using a Web-Based Survey Technique. Pediatrics, 115(4), 861-867.

10) Clark, A. D. (2013). Effectiveness Of The Dangerous Decibels 
Program In Children When Delivered With Parental Involvement. A Capstone Research Project Submitted in Partial Fulfillment of the Requirements for the Degree of Doctor of Audiology. Greeley, Colorado: University Of Northern Colorado, College of Natural and Health Sciences Audiology \& Speech Language Sciences Audiology.

11) Crandell, C., Mills, T. L. i Gauthier, R. (2004). Knowledge, Behaviours and Attitudes About Hearing Loss and Hearing Protection Among Racial/Ethnically Diverse Young Adults. Journal Of The National Medical Association, 96, 176-186.

12) Danhauer, J. L., Johnson, C. E., Dunne, A. F., Young, M. D., Rotan, S. N., Snelson, T. A., Stockwell, J. S. i McLaina. M. J. (2012). Survey of High School Students' Perceptions About Their iPod Use, Knowledge of Hearing Health, and Need for Education. Language, Speech, and Hearing Services in Schools, 43(1), 14-35.

13) Davis, A., Smith, P., Ferguson, M., Stephens, D. i Gianopoulos, I. (2007). Acceptability, benefit and costs of early screening for hearing disability: a study of potential screening tests and models. Health Technol Assess, 11(42), 1294.

14) Folmer, R. L. (2005). Noise-induced hearing loss in young people. Noise and Health, 7(29), 41-42.

15) Folmer, R. L., Griest, S. E. i Martin, W. H. (2002). Hearing conservation education programs for children: A review. Journal of School Health, 72, 51-7.

16) Gilles, A., De Ridder, D., Van Hal, G., Wouters, K., Kleine Punte, A. i Van de Heyning, P. (2012). Prevalence of Leisure Noise-Induced Tinnitus and the Attitude Toward Noise in University Students. Otology and Neurology, 33(6), 899-906.

17) Griest, S. E., Folmer, R. L. i Martin, W. H. (2008).

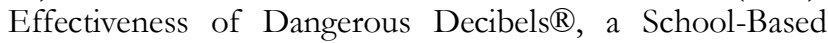
Hearing Loss Prevention Program. American Journal of Audiology, 16(2), S165-S181.

18) Gurgel, R. K., Ward, P. D., Schwartz, S., Norton, M. C., Foster, N. L. i Tschanz, J. A. T. (2014). Relationship of Hearing loss and Dementia: a Prospective, Population-based Study. Otol Neurotol, 35(5), 775-781.

19) Hogan A. (2001). Hearing Rehabilitation for Deafened Adults: A psychosocial Approach. London: Whurr Publishers. str. 28.

20) Hogg, M. A. i Vaughan, G. M. (2010). Essentials of Social Psychology. Harlow, England: Pearson Education Limited

21) Katz, D. (1960). The functional approach to the study of attitudes. Public Opinion Quarterly, 24, 163-204.

22) Keppler, H., Dhooge, I. i Vinck, B. (2015). Hearing in young adults. Part I: The effects of attitudes and beliefs toward noise, hearing loss, and hearing protector devices. Noise \& Health, 17(78), 237-244.

23) Kochkin, S. (2012). Marke'Trak VIII: The key influencing factors in hearing aid purchase intent. HearRev, 19(3), 12-25.

24) McMahon, C. M., Gopinath, B., Schneider, J., Reath, J., Hickson, L., Leeder, S. R. i sur. (2013). The Need for Improved Detection and Management of Adult-Onset Hearing Loss in Australia. Int J Otolaryngol, 2013, 1-7.

25) Meinke D. i Dice, N. (2007). Comparison of Audiometric Screening Criteria for the Identification of Noise-Induced Hearing Loss in Adolescents. American Journal of Audiology, 16, S190-S202.

26) Monzani, D., Galeazzi, G. M., Genovese, E., Marrara, A., Martini, A. (2008). Psychological profile and social behavior of working adults with mild or moderate hearing loss. Acta Otorbinolaryngol Ital, 28(2), 61-66.

27) Naramura, H., Nakanishi, N., Tatara, K., Ishiyama, M., Shiraishi, H. i Yamamoto, A. (1999). Physical and mental correlates of hearing impairment in the elderly in Japan. Audiology, 38(1), 24-29.

28) National Institute on Deafness and Other Communication Disorders (NIDCD) (2016). Quick Statistics About Hearing. Posjećeno 09.12.2017. na mrežnoj stranici https://www.nidcd.nih.gov/health/statistics/quick-

statistics-hearing

29) Nelson, D. I., Nelson, R. Y., Concha-Barrientos, M., Fingerhut, M. (2005). The Global Burden of Occupational Noise-induced Hearing Loss. American Journal of Industrial Medicine, 48(6), 446-58.

30) Olsen Widén, S. E. i Erlandsson, S. I. (2004). Selfreported tinnitus and noise sensitivity among adolescents in Sweden. Noise and Health, 7(25), 29-40.

31) Perloff, R. M. (2016). The Dynamics of Persuasion: Communication and Attitudes in the Twenty-First Century. Abingdon: Routledge.

32) Power, B. (1992). Attitudes Of Young People To Ageing And The Elderly. Report no. 16. Dublin, Ireland: National Council For The Elderly.

33) Pronk, M., Kramer, S. E., Davis, A. C., Stephend, D., Smith, P. A., Thodi, C. i sur. (2011). Interventions following hearing screening in adults: A systematic descriptive review. Int J Audiol, 20, 594-609.

34) Rosandić, M. i Bonetti, L. (2014). Izloženost mladih u Hrvatskoj buci - navike, stavovi, svijest o riziku, uporaba zaštite i rane posljedice. Logopedija, 4(1), 31-41.

35) Ross, M. (2000). When a Hearing Aid is Not Enough. Hear Rev, 7, 26-30.

36) Sindik, J. (2014). Osnove istraživačkog rada u sestrinstvu. Dubrovnik: Sveučilište u Dubrovniku.

37) Southall, K., Gagné, J. P. i Jennings, M. B. (2010). Stigma: a negative and a positive influence on help-seeking for adults with acquired hearing loss. Int J Audiol, 49(11), 804-814.

38) Stock, J. (2014). Physical activity and cognitive ability in older adults: the role of psychosocial factors. Leicestershire, UK: Loughborough University.

39) Strawbridge, W. J., Wallhagen, M. I., Shema, S. J. i Kaplan, G. A. (2000). Negative consequences of hearing impairment in old age: a longitudinal analysis. Gerontologist, 40(3), 320-326.

40) Trychin, S. (2002). Guidelines for Providing Mental Health Services to People who are Hard of Hearing (Rep. No. ED466082). San Diego, SAD: California University.

41) Verma, L., Sanju, H. K., Scaria, B., Awasthi, M., Ravichandran, A., Kaki, A. i Prakash, S. G. R. (2017). A Comparative Study on Hearing Aid Benefits of Digital Hearing Aid Use (BTE) from Six Months to Two Years. International Archives of Otorbinolaryngology, 21, 224-231.

42) Wallhagen, M. I. (2010). The Stigma of Hearing Loss. Gerontologist, 50(1), 66-75.

43) Widen, S., Bohlin, M., Johansson, I. (2011). Gender perspectives in psychometric related to leisure time noise exposure and use of hearing protection. Noise and Health, 13(55), 407-414.

44) World Health Organization (2013). Million of people in the world have hearing loss that can be treated or prevented. Geneva: WHO Press. 
45) World Health Organization (2017). Deafnessand hearing loss. Fact sheet. Posjećeno 10.12.2017. na mrežnoj stranici

http://www.who.int/mediacentre/factsheets/fs300/en. 